\title{
CDIO is a marker for cycling cells with propensity to apoptosis in childhood ALL
}

\section{G Cutrona*,1,5, P Tasso4, M Dono ${ }^{1,5}$, S Roncella' ${ }^{1,6}$, M Ulivi ${ }^{1,7}$, EM Carpaneto ${ }^{2,5}$, V Fontana ${ }^{3}$, M Comis ${ }^{8}$, F Morabito', M Spinelli ${ }^{10}$, E Frascella ${ }^{10}$, LC Boffa ${ }^{2}$, G Basso ${ }^{10,11}$, V Pistoia ${ }^{4}$ and M Ferrarini ${ }^{1,5}$}

\begin{abstract}
'Servizi di Immunologia Clinica, Istituto Nazionale per la Ricerca sul Cancro, IST, Genoa, Italy; ${ }^{2}$ Oncologia Sperimentale, Istituto Nazionale per la Ricerca sul Cancro, IST, Genoa, Italy; ${ }^{3}$ Epidemiologia Ambientale e Biostatistica, Istituto Nazionale per la Ricerca sul Cancro, IST, Genoa, Italy; ${ }^{4}$ Laboratorio di Oncologia, Istituto G Gaslini, Genoa, Italy; ${ }^{5}$ Dipartimento di Oncologia, Biologia e Genetica, Università di Genova, Genoa, Italy; ' Servizio di Istologia e Anatomia Patologica, Ospedale Sant' Andrea, La Spezia, Italy; ${ }^{7}$ TIB-Mol Biol, Berlin, Germany; ${ }^{8}$ Divisione di Ematologia, Dipartmento di Ematologia, Azienda Ospedaliera Bianchi-Melacrino-Morelli, Reggio Calabria, Italy; ${ }^{9}$ Centro Trapianti Midollo Osseo, Dipartimento di Ematologia, Azienda Ospedaliera Bianchi-Melacrino-Morelli, Reggio Calabria, Italy; ${ }^{10}$ Laboratorio di Emato-Oncologia, Azienda Ospedaliera, Università Padova, Padua, Italy;

"Dipartimento di Scienze Pediatriche Torino, Turin, Italy
\end{abstract}

CDIO constitutes a favourable prognostic marker for childhood acute lymphoblastic leukaemia. Since correlations between CDIO, cell cycle and apoptotic abilities were demonstrated in various cell types, we investigated whether differences existed in the cycling/apoptotic abilities of CDI0-positive and CDI0-negative B acute lymphoblastic leukaemia cells. Twenty-eight cases of childhood acute lymphoblastic leukaemia (mean age of 6.8 years) were subdivided into two groups according to high (I7 cases, 93.2 $\pm 4.5 \%$, MRFI $211 \pm 82$ CDI0-positive cells) or low (II cases, II.5 $\pm 6.2 \%$, MRFI I0 \pm 7 CDI0-negative cells) expression of CDI0. CDIO-positive acute lymphoblastic leukaemia cells were cycling cells with elevated c-myc levels and propensity to apoptosis, whereas CDI0-negative acute lymphoblastic leukaemia cells had lower cycling capacities and c-myc levels, and were resistant to apoptosis in vitro. A close correlation between all these properties was demonstrated by the observations that the few CDI0-positive cells found in the CDI0-negative acute lymphoblastic leukaemia group displayed elevated c-myc and cycling capacities and were apoptosis prone. Moreover, exposure of CDI0-positive acute lymphoblastic leukaemia B cells to a peptide nucleic acid anti-gene specific for the second exon of c-myc caused inhibition of c-myc expression and reduced cell cycling and apoptotic abilities as well as decreased CDI0 expression.

British Journal of Cancer (2002) 86, 1776 - 1785. doi:I0.1038/sj.bjc.6600329 www.bjcancer.com

(c) 2002 Cancer Research UK

Keywords: B lymphocytes; apoptosis; cell surface molecules; cellular proliferation

Malignant B cells from the majority of childhood acute lymphoblastic leukaemia (ALL) cases are characterised by the surface expression of CD10, previously known as common acute lymphoblastic leukaemia antigen or CALLA (as reviewed in LeBien and McCormack, 1989; Shipp and Look, 1993; Weir and Borowitz, 2001). Although initially considered a tumour specific antigen, CD10 was subsequently detected on a variety of normal cells of haemopoietic and non haemopoietic origin. CD10, also called neutral peptidase 24.11 or NEP, possesses a well-defined enzymatic activity, but its function in the physiology of lymphoid cells is largely unknown. From the standpoint of childhood ALL, CD10 expression represents a favourable, although not independent, prognostic marker (Pui et al, 1993; Consolini et al, 1998). The reason as to why a surface molecule has impact on prognosis is not known, although a number of observations on other cell types suggest that CD10 may mark cells with special cycling and apoptotic abilities. For example, CD10 was found on the surface of cells that are particularly prone to apoptosis such as normal germinal centre B cells (Liu et al, 1992) or malignant cells from Burkitt's

* Correspondence: G Cutrona, U.O. Immunologia Clinica, Istituto Nazionale Per La Ricerca Sul Cancro, IST, Largo Rosanna Benzi, n. 10, I6I32 Genoa GE, Italy; E-mail: giovanna.cutrona@istge.it Revised 7 March 2002; accepted 27 March 2002
Lymphomas (BL) (Rowe et al, 1987). Moreover, it was observed that CD10 was expressed by $\mathrm{T}$ cells induced into apoptosis by a variety of means in vitro (Cutrona et al, 1999). Finally, c-myc upregulation not only induces cell entry into the early phases of cell cycle, but also renders the cells apoptosis-prone and concomitantly induces CD10 expression (Cutrona et al, 1995, 2000).

Based on the above observations, we reasoned that expression of CD10 by malignant B cells from ALL might indicate a special cycling ability as well as a propensity to undergo apoptosis. Indeed, in this study we demonstrate that expression of CD10 marks malignant ALL cells that are apoptotis-prone and actively cycling and express high levels of the c-myc oncogene. By contrast, CD10-negative ALL cells have lower c-myc levels and inferior cycling and apoptotic properties under the same in vitro conditions. CD10positive ALL comprise different subgroups characterised by distinctive cytogenetic abnormalities. Nevertheless all of these cells appear to share the same cycling/apoptotic features, which can represent a common prognostic factor.

\section{MATERIALS AND METHODS}

\section{Patients}

Bone marrow aspirates of 28 cases of childhoood pre-B ALL (mean age of 6.8 years) were obtained from hospitals affiliated with the 
Italian Association of Pediatric Hematology and Oncology (AIEOP). Diagnosis of B ALL was based on morphological analysis of bone marrow aspirates according to the French-AmericanBritish (FAB) guidelines (Bennett et al, 1981), and on cytochemical and phenotypic features of the leukaemia cells. Such features include positive nuclear staining for terminal deoxynucleotidil transferase, negative staining for myeloperoxidase, expression of B-cell differentiation markers such as CD19 and cytoplasmic Ig $\mu$ chains and absence of surface Ig. Karyotype analysis did not reveal any chromosomal abnormality in which the c-myc oncogene could be involved, i.e. $\mathrm{t}(8 ; 14), \mathrm{t}(2 ; 8)$, or $\mathrm{t}(8 ; 22)$ (Magrath, 1990). At the time of study, ALL patients were at the onset of disease and were untreated. All the bone marrow samples were stored in liquid nitrogen $\left(-180^{\circ} \mathrm{C}\right)$ until tested. In the experiments with PNAs (see below), freshly prepared cells from cases \#655, 657, 659, 660 and 661 were employed.

\section{Cytogenetic analysis}

Bone marrow aspirates were processed as previously described (Sainati et al, 1997). The cytogenetic studies were performed using Trypsin-Giemsa banding technique. Chromosomes were identified and assigned according to the International System for Human Cytogenetic Nomenclature (Mitelman, 1995).

\section{Detection of specific chromosome gene aberration by RT - PCR}

Total RNA was isolated by using the RNAzol-B reagent according to the manufactory protocol (Duotech srl Milan, Italy). Two micrograms of total RNA from each specimen was reversed transcribed by using the Superscript reverse trascriptase (Life Technologies Milan, Italy) and random examers: PCR amplification was performed using Amplitaq polymerase (Applied Byosistem) according to BIOMED-1 (van-Dongen et al, 1999) protocols. A screening for the following fusion gene transcripts $t(1 ; 19)$ with E2A-PBX1, $t(4 ; 11)$ with MLL-AF4, $t(9 ; 22)$ with BCR-ABL p190 and BCR-ABL p210, $\mathrm{t}(12 ; 21)$ with TEL-AML1, was performed. An indipendent PCR reaction was performed with shift primers for confirmation of each positive result. The ABL housekeeping gene expression was assessed to determine the presence of amplificable RNA and the efficacy of reverse transcriptions. The electrophoresed PCR reaction products were stained with ethidiun bromide.

\section{Cells and cell cultures}

Mononuclear cell fractions were purified from bone marrow aspirates by centrifugation on Ficoll-Hipaque gradients (Seromed, Biochrom KG, Berlin, Germany). All of the suspensions were comprised of more than $90 \%$ leukaemia cells except for cases \#738 and 702, in which there were 55 and 69\% leukaemic cells, respectively. Where indicated, special staining procedures had to be employed for these cases.

The LAM C4 cell line, derived from a Burkitt lymphoma patient, with the typical $t(8 ; 14)$ translocation and $c-m y c$ over-expression was used as a positive control in the studies on c-myc expression (Roncella et al, 1993).

The culture medium used throughout was RPMI 1640 (Seromed) supplemented with 10\% FCS (Seromed).

\section{Flow-cytometry}

The following mAbs were used for immunofluorescence staining: anti CD10 (J5) (Coulter Corp., Hielah, FL, USA), and anti CD19 (Leu-12) (Becton Dickinson \& Co., Sunnyvale, CA, USA). Both of these mAbs were used in indirect immunofluorescence. The secondary FITC- or PE-conjugated antibodies to the appropriate murine Ig isotype were from Southern Biotechnology (Birmingham, AL, USA). Permeabilised cells were stained for indirect immunofluorescence with a murine anti Myc mAb (6E10 clone, Cambridge Research Biochemicals, Cheshire, UK), an anti Ki67 mAb (DAKOPATTS, Glostrup, Denmark), and an anti Ig $\mu$ chains (Becton Dickinson \& Co.) as previously reported (Cutrona et al, 1997). The samples were analysed by flow cytometry (FACS Calibur, Becton Dickinson \& Co.). Data were expressed as histograms of fluorescence intensity $v s$ cell number or as relative fluorescence intensity (MRFI) calculated according to the following formula: mean fluorescence intensity of cells stained with the $\mathrm{mAb} /$ mean fluorescence intensity of control cells treated with an unrelated mAb.

Two-colour analysis of 5-bromo-deoxyuridine (BrdUrd) (Sigma Aldrich, Milan, Italy) incorporation and DNA content was performed according to a modification of the method of Dolbeare et al (1985) as previously described (Dolbeare et al, 1985; Cutrona et al, 1997).

CD10 positive and negative cells from CD10-negative ALL cases were separated by cell sorting (FACS Calibur, Becton Dickinson \& Co.). The two populations were gated on the basis of CD10 expression and the forward light scatter parameter.

Measurements of ploidy (DNA index, DI) was carried out by staining samples with a hypotonic solution of PI using an automated DNA staining device (DNA-prep reagents; Coulter) and analysed by flow cytometry (Epics XL; Coulter). DNA histograms were obtained by a cell cycle analysis program (Multicycle; Phoenix, San Diego, CA, USA). Leukaemic cells were classified as diploid when the DI was between 0.9 and 1.09; as hyperdiploid when the DI was 1.8 and less then 1.80; and as hypodiploid when DI was < 0.9 . The DI was established from the ratio of the modal channel number of the G0/G1 peak of neoplastic cells to that of normal cells.

\section{Western blot}

Western blot analysis for MYC protein was performed as previously described (Cutrona et al, 1995). The nitrocellulose membranes were immunoblotted with an anti Myc hybridoma supernatant (9E10 clone, kindly provided by $\mathrm{Dr}$ R Sitia, San Raffaele Institute, Milan, Italy) or a rabbit antiserum to histone 2b (H2b) (kindly provided by Dr U Pfeffer, CBA, Genoa, Italy).

\section{PCR methodologies}

The PCR technique for analysis of $\mathrm{V}(\mathrm{D}) \mathrm{J}$ rearrangements and of HCDR3 length was performed as previously described (Dono et $a l$, 1996). A RT-PCR methodology was used to detect c-myc and glyceraldehyde 3-phosphate dehydrogenase (GAPDH) RNA expression by the leukaemia cells treated in different manners (Cutrona et al, 1997).

\section{Apoptosis assays}

Five $\times 10^{5}$ per $\mathrm{ml}$ cells were cultured in RPMI medium (Seromed) supplemented with $10 \%$ FCS (Seromed). The cultures were harvested at different intervals and the apoptotic cells were detected by using Annexin-V conjugated with FITC (Apolert ${ }^{\mathrm{tm}}$ Apoptosis Kit, Clontech Laboratories Inc., Palo Alto, CA, USA), by PI staining, or by DNA laddering, as previously described (Cutrona et al, 1999).

\section{PNA anti-gene}

A 17-mer anti myc PNA, complementary to a unique sequence located at the beginning of the second exon of the c-myc oncogene (TCA ACG TTA GCT TCA CC) was used. This PNA was modified by addition of a Nuclear Localization Signal peptide (NLS) PNA- 
$\mathrm{myc}_{\mathrm{wt}}-\mathrm{NLS}$ as reported (Cutrona et al, 2000). A PNA characterised by a 3-base substitution (TTA ACG CTA GCT TTA CC), but unchanged purine/pirimidine ratio (PNA-myc $\mathrm{c}_{\text {mut }}-\mathrm{NLS}$ ) was used as control. The PNAs described were purchased from TIB MOLBIOL (Berlin, Germany).

\section{Statistical methods}

Mean, standard deviation, and standard error were calculated for each of the markers determined for the two groups of patients investigated. Mean differences by groups of patients were evaluated via the Student's $t$-test and, when necessary (i.e., skewness and/or heteroscedasticity in the biomarker distributions), statistical testing was applied on long transformed variables (Armitage and Berry, 1987). All statistical comparisons and related $P$-values were two tailed. Mean differences were considered significant when $P$-values were less than or equal to 0.05 .

\section{RESULTS}

\section{Definition of CD10-positve and CD10-negative ALL}

The cells from the bone marrow of 28 ALLs of B cell origin were simultaneously stained for CD10 and CD19. As shown in Figure 1, the ALL cases were subdivided into two groups: one (17 cases) with a high CD10 expression ( $>80 \%$ CD19-expressing cells were CD10 positive, MRFI $211 \pm 82$ ), and one (11 cases) with low CD10 ( $\leqslant 20 \%$ CD19-expressing cells were CD10 posi-

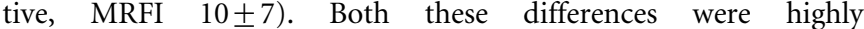
significant $(P<0.001$ for both percentage positive cells and MRFI values). Cases belonging to the first group, i.e. high CD10 expression, were defined as CD10-positive, while cases falling in the second group, i.e. low CD10 expression, were considered as CD10-negative.

Next, we investigated whether correlations existed in the different cases between the presence of certain chromosome abnormalities and CD10 expression. The 28 ALLs of B cell origin were analysed for the fusion gene transcripts $t(1 ; 19)$ with E2APBX1, $\mathrm{t}(4 ; 11)$ with MLL-AF4, $\mathrm{t}(9 ; 22)$ with BCR-ABL p190 and BCR-ABL p210, $\mathrm{t}(12 ; 21)$ with TEL-AML1 by RT-PCR. As shown in Table 1 only one out of 14 CD10-positive and two out of 10 CD10-negative ALL cases displayed the $\mathrm{t}(4 ; 11)$ translocation, three out of 14 CD10-positive ALL cases displayed $t(12 ; 21)$ rearrangement and $t(9 ; 22)$ was negative in all of the cases analysed. Notably, because of the study design, all of the cases tested did not display any of the typical translocations of BL (Magrath, 1990).

\section{Differences in spontaneous apoptosis in vitro}

Here, we investigated whether the malignant cells from CD10-positive ALL had higher spontaneous apoptotic capacities than those from CD10-negative cases. Apoptosis was measured by PI staining in cells taken ex vivo or after $24 \mathrm{~h}$ in culture. While the proportion of apoptotic cells in the suspensions ex vivo was very low in the two groups (mean $4 \pm 3.8$ ) (Figure 2), significant differences were noted after culture. Apoptotic cells in the CD10-positive ALL group were $66.7 \pm 9.1 \%$ vs $22.3 \pm 10.5 \%$ in the other group $(P<0.001)$. These differences were further confirmed by measuring the DNA laddering (Figure 2).

\section{Differences in cell cycle status}

Next, we investigated the cell cycling abilities of CD10-positive and CD10-negative ALL cells. Eight CD10-positive and seven CD10-negative ALL cases were stained for Ki67, which is expressed from the late G1 phase of the cell cycle (Gerdes et $a l, 1984)$. The proportion of Ki67-expressing cells was signifi-

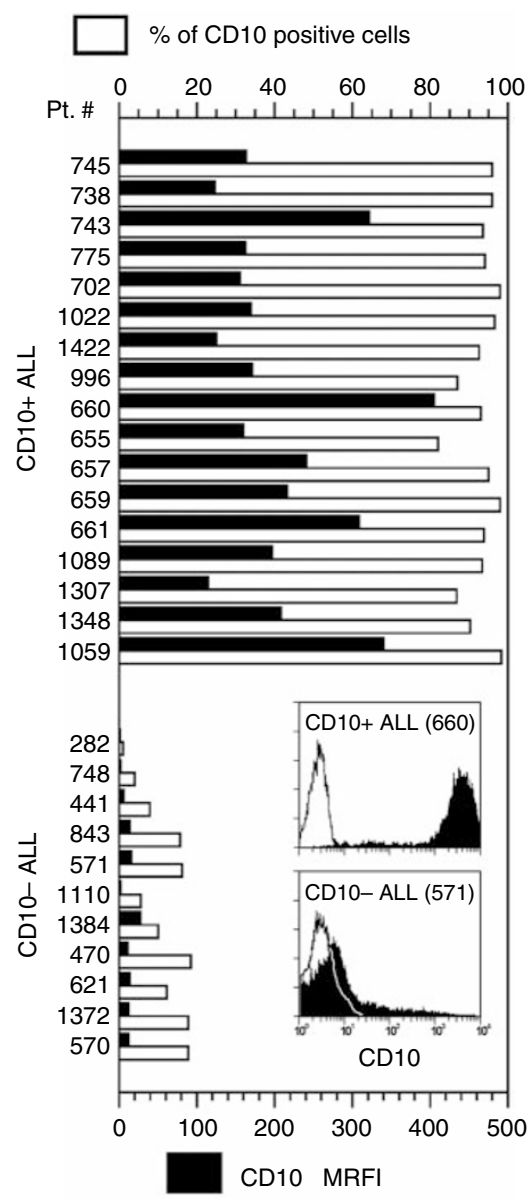

Figure I Definition of CDI0-positive and CDI0-negative ALL. Bone marrow cell suspensions were stained for CDI9 and CD I0. CD I9-positive cells were gated and the percentage of CDI0-positive (top scale) cells or the MFRI for CDIO (bottom scale) were recorded. Two typical flow cytometry profiles for CDIO are also shown.

cantly higher in the CD10-positive than in the CD10-negative ALL cases $(63.66 \pm 23 \%$ vs $27.37 \pm 9.4 \%, P=0.009$, see Figure $3 \mathrm{~A})$. Figure $3 \mathrm{~A}$ also shows typical flow cytometry profiles where a bimodal distribution of Ki67-positive cells is evident for each group.

In another experiment, we investigated BrdUrd incorporation by the CD10-positive and CD10-negative ALL following $1 \mathrm{~h}$ in culture. The incorporation of BrdUrd was much higher in the CD10-positive than in the CD10-negative ALLs (average $47.52+21.27 \%$ vs $7.66 \pm 7.84 \%, P=0.001$ ) (Figure 3B). Figure 3B also shows a typical flow cytometry profile obtained in a test where the cells were pulsed with BrdUrd for $1 \mathrm{~h}$, PI stained and analysed by flow cytometry. Most of the cells from the CD10-positive ALL were in the G1-S phase, whereas the majority of the cells from the CD10-negative ALL were in the G0-G1 phase of the cell cycle, a finding which is in agreement with the results of the Ki67 staining.

The cells from five CD10-positive ALL cases (775, 743, 1022, 745 and 657) were pulsed with BrdUrd for different time intervals before PI staining and flow cytometry analysis. Most of the cells were already in the $\mathrm{S}$ phase of the cell cycle after $1 \mathrm{~h}$. At later times, there were very few cells in the $M$ phase, whereas the majority of the cells underwent apoptosis from the G1-S phase of the cell cycle, as shown by the finding that virtually all of the hypodiploid cells seen at $48 \mathrm{~h}$ had also incorporated BrdUrd (Figure 3C). 
Table I Cytogenetic analysis of CDI0-positive and CDI0-negative B-ALL

\begin{tabular}{|c|c|c|c|c|c|c|c|c|}
\hline Patient & CDI0 \% & Cariotype $^{b}$ & Ploidy $^{c}$ & $t(|2 ; 2|)$ & $t(4 ; 11)$ & $t(1 ; 19)$ & $t(9 ; 22)$ p 190 & $t(9 ; 22)$ p2 10 \\
\hline 745 & 95.9 & $46, X Y$ & diploid & $+^{d}$ & $-{ }^{d}$ & - & - & - \\
\hline 738 & 55.1 & $46, X Y$ & hyperdiploid & + & - & - & - & - \\
\hline 743 & 93.6 & $n d^{e}$ & diploid & - & - & - & - & - \\
\hline 702 & 69.1 & $46, X Y$ & nd & - & - & - & - & - \\
\hline 1022 & 96.6 & nd & diploid & - & - & - & - & - \\
\hline 1422 & 92.6 & $46, X Y, \operatorname{der} 3, \operatorname{der} 12$ & diploid & + & - & - & - & - \\
\hline 1348 & 90.3 & $46 X X,(15 \%) / 47, X X Y, t(4 ; 1$ I)(q2।;q23)(85\%) & hyperdiploid & - & + & - & - & - \\
\hline 1089 & 93.4 & $45, X X,-20$ & hypodiploid & - & - & - & - & - \\
\hline 655 & 82 & nd & nd & nd & nd & nd & nd & nd \\
\hline 657 & 95 & $46, X Y$ & hyperdiploid & - & - & - & - & - \\
\hline 659 & 98 & nd & nd & nd & nd & nd & nd & nd \\
\hline 660 & 93 & $46, X X$ & diploid & - & - & - & - & - \\
\hline 571 & 16.2 & $46, X Y$ & diploid & - & - & - & - & - \\
\hline 1110 & 5.6 & $46, X Y$ & hypodiploid & - & - & - & - & - \\
\hline 1384 & 10 & $47, X X,+21$ & nd & - & - & - & - & - \\
\hline 470 & 18.5 & nd & nd & - & - & - & - & - \\
\hline 621 & 12.3 & nd & nd & - & - & - & - & - \\
\hline 1372 & 17.8 & $46, X X$ & diploid & - & - & - & - & - \\
\hline 570 & 17.8 & $46, X Y$ & diploid & - & - & - & - & - \\
\hline
\end{tabular}

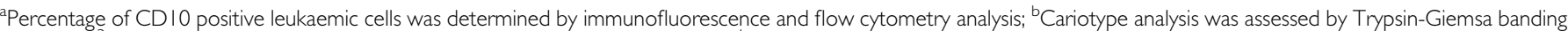
technique; ${ }^{3}$ Ploidy was defined based upon DI values (see Materials and methods); ${ }^{d}+$ and - indicate presence or absence of fused gene transcripts by PCR analysis, respectively; end=not determined.
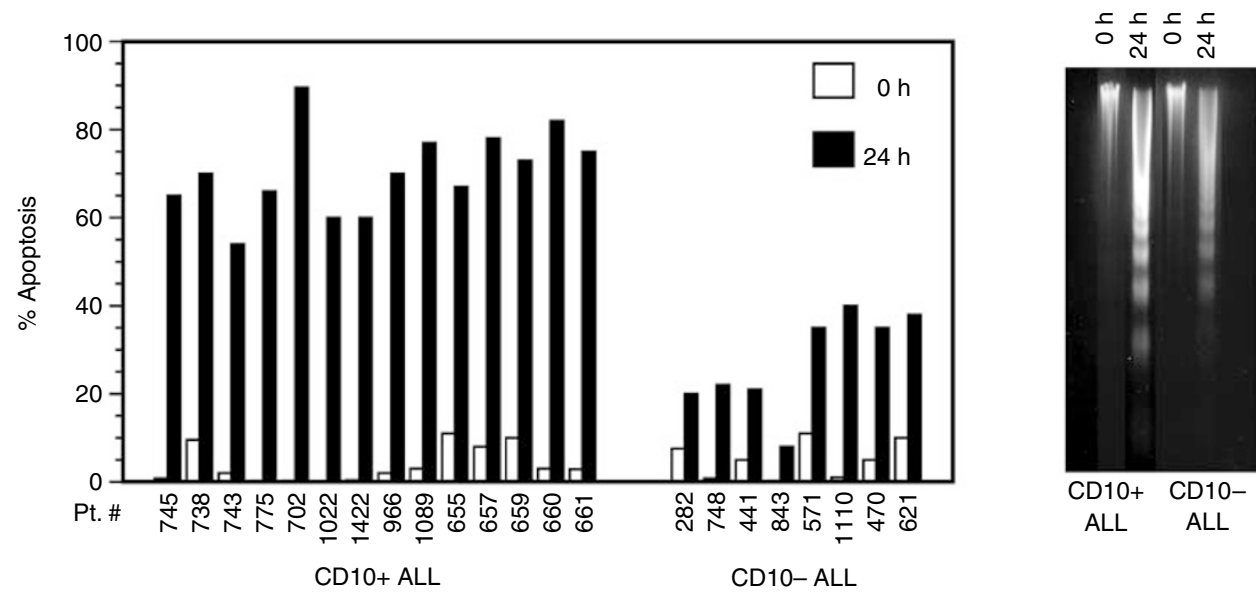

Figure 2 Apoptotic capacities of CDI0-positive and CDI0-negative ALL cells. Cells from the indicated cases were tested for apoptosis by PI staining either immediately after isolation or following $24 \mathrm{~h}$ in culture (left). Apoptotic capacities were confirmed by measuring DNA laddering (two typical experiments are shown on the right).

\section{Differences in Myc expression}

Cell undergoing apoptosis from the G1-S phase of the cell cycle often overexpress c-myc (Hueber and Evan, 1998). To explore this issue further, CD10-positive and CD10-negative ALL were analysed for the expression of Myc protein by immunofluorescence. Single staining was carried out in all cases in which there were greater than $80 \%$ neoplastic cells (i.e., $\mathrm{CD}^{+} 9^{+}$ $\mathrm{CD} 10^{+}$or $\mathrm{CD} 19^{+} / \mathrm{CD} 10^{-}$large blasts), while in two cases, where the proportion of malignant cells was lower (\#738 and 702), double staining for surface CD19 and intracytoplasmic Myc was carried out. The data, summarised in Figure 4A, show a significant difference in Myc expression. CD10 positive ALL cases had an average MRFI of $69.24 \pm 25.3$ vs $14.98 \pm 6$ of CD10-negative ALL cases $(P<0.001)$. These findings were confirmed by Western blot analysis (Figure 4B). The percentages of cells positive for Myc were not determined since the cells of both groups displayed some positive fluorescence, as indicated by the typical profiles shown in the inset of Figure 4A. It could be argued that because of its relatively short half life (Hann and Eisenman, 1984), Myc expression was influenced by the cryopreservation of the cells. However, extensive comparative tests carried out 

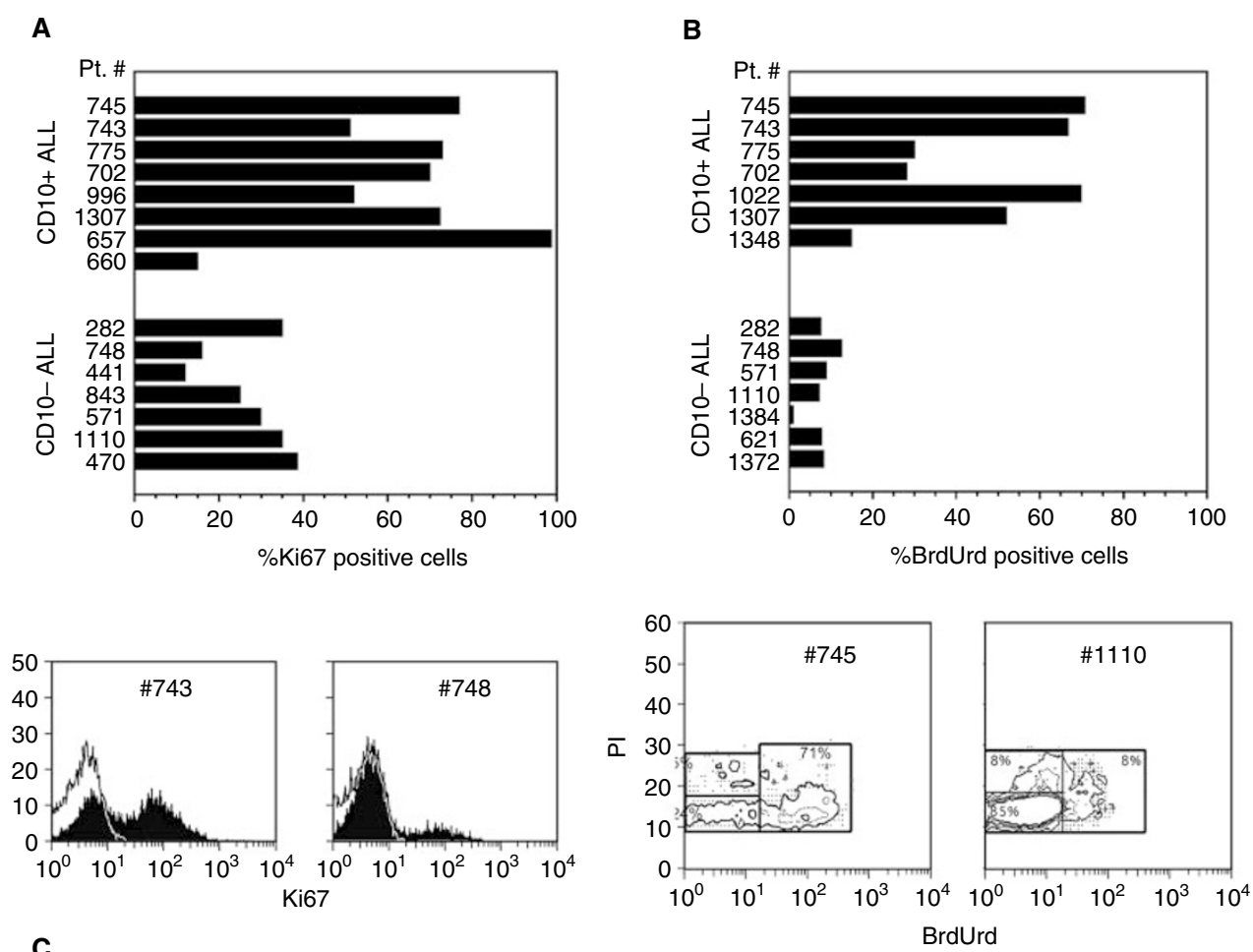

C
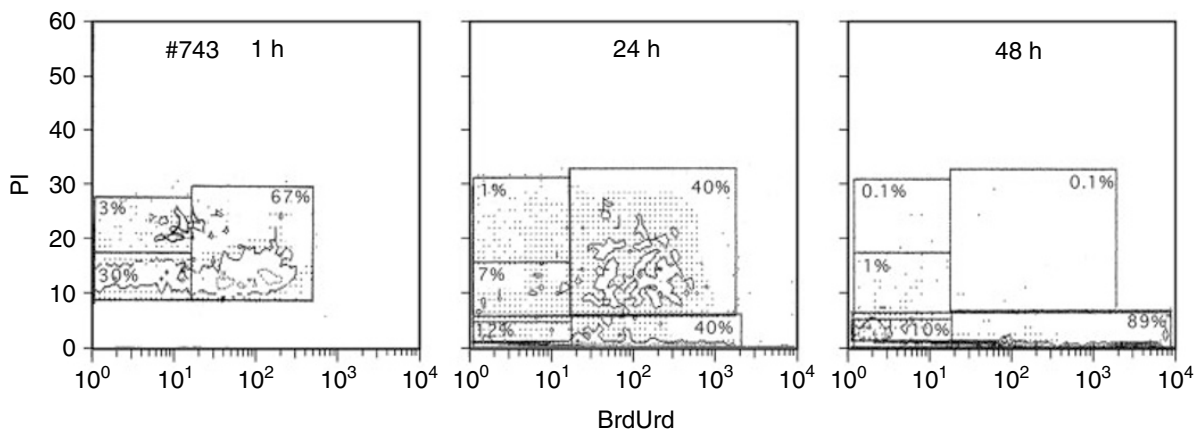

Figure 3 Cell cycle status of CD I0-positive and CD I0-negative ALL. (A and B) Cells from the indicated cases were stained for Ki67 (A) or BrdUrd (I h pulse) (B) and analysed by flow cytometry. Typical profiles of CD I 0-positive or CD I 0-negative ALL cases are shown at the bottom of each figure. (C) Cells from a CDI0-positive ALL were pulsed with BrdUrd for the indicated times, stained for PI and analysed by flow cytometry. Apoptotic (hypodiploid cells) are observed in the gates at the bottom of the figures.

in case 657 demonstrated that cryopreservation did not affect Myc expression. Moreover, cases $(655,657,659,660,661)$ were also tested using freshly drawn cells.

\section{Features of CD10-positive cells isolated from CD10- negative ALL cases}

Next, we investigated the characteristics of the few CD10-positive cells detected in the CD10-negative ALL cases. The cells from six cases $(571,1372,621,1384,470$ and 843) were stained with $\mathrm{CD} 10 \mathrm{mAb}$ and the CD10-positive cells were FACS-sorted. Sufficient quantities of CD10-positive and CD10-negative cells could be isolated for further analyses. As shown in Figure 5 (which reports one representative experiment on cells from patient \#571), CD10-positive cells were actively cycling, with high levels of $c-m y c$ and a special propensity to undergo apoptosis in vitro, whereas CD10-negative cells had low c-myc levels and low cycling and apoptotic capacities (Figure 5). These data demonstrate a different functional status in two cell populations that originated from the same clone, as shown by the analyses of their $\mathrm{V}(\mathrm{D}) \mathrm{J}$ rearrangements (see Figure 5).

\section{Role of c-myc in apoptosis, cell cycle and CD10 expression}

Here, we tested the hypothesis that the high level of c-myc conferred to CD10-positive ALL cells both a superior cycling capacity and a more pronounced propensity to undergo apoptosis. To this end, c-myc expression was blocked using a PNA anti c-myc anti-gene. PNAs are synthetic structural homologues of nucleic acids in which the phosphate-sugar polynucleotide backbone is replaced by a flexible polyamide (Egholm et al, 1992). They can bind to the complementary DNA sequences more stably than DNA itself (Egholm et al, 1993). However, to be effective on intact cells in vitro, PNAs must be coupled to a vector, which allows their transport to the cell nuclei (Nielsen, 1999). In this study, we used PNA with complementarity to a sequence of the second exon of the c-myc oncogene. When coupled to an appropriate nuclear localisation sequence (NLS), this PNA-myc $\mathrm{wt}_{\mathrm{wt}}$-NLS is able to penetrate cell nuclei and to selectively block the expression of $c-m y c$ (Cutrona et al, 2000). A PNA that differed for the presence of three mutations in the sequence complementary to the c-myc sequence was used as control (PNA-myc mut $^{-N L S)}$. 
A

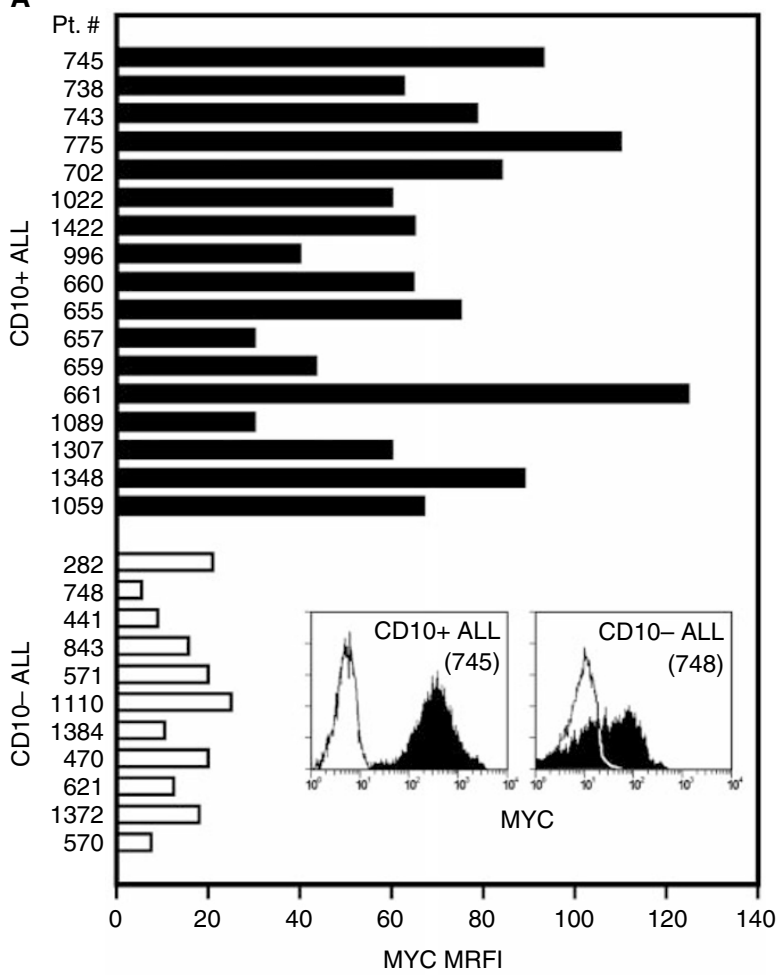

B

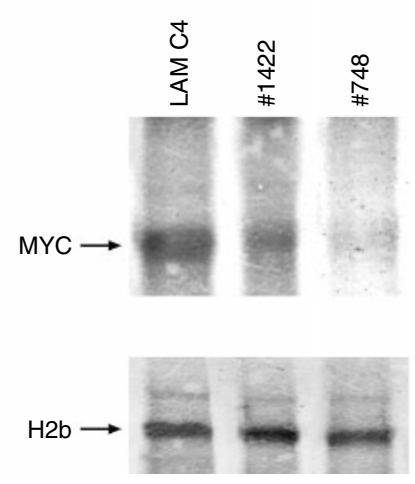

Figure 4 c-myc expression by ALL cells. (A) Cells from CD I0-positive or CD I0-negative ALL were stained for MYC protein following permeabilisation (see Materials and methods for details). The fluorescence detected by flow cytometry is expressed as MFRI. Two typical flow cytometry profiles are shown. (B) Western blot analysis of Myc expression by the cells from one CDIO-positive (\#|422) and one CDI0-negative (\#748) ALL case and by the BL cell line LAM C4. The Western blot was run with purified cell nuclei and probed with an anti Myc or an anti histone $2 b$ antibody. This is a representative experiment of tests carried out on five CDI0-positive and four CDI0-negative ALL cases.

Cells from CD10-positive ALL were incubated with medium, $10 \mu \mathrm{M}$ PNA-myc $\mathrm{wt}_{\mathrm{wt}}-\mathrm{NLS}$, or PNA-myc $\mathrm{mut}^{-\mathrm{NLS}}$ for $24 \mathrm{~h}$. The cultured cells were harvested and checked for c-myc expression by flow cytometry (Figure 6A), RT-PCR (Figure 6B) and Western blot (Figure 6C). As shown in Figure 6, a mean reduction in MRFI of $54 \pm 18 \%$ was noticed by immunofluorescence and flow cytometry. This reduction in $c-m y c$ expression was confirmed by the two other methods. Inhibition of c-myc expression was accompanied by a significant decrease of BrdUrd incorporation by the cells (Figure $6 \mathrm{D})$, indicating a substantial decline in their cycling abilities.
A
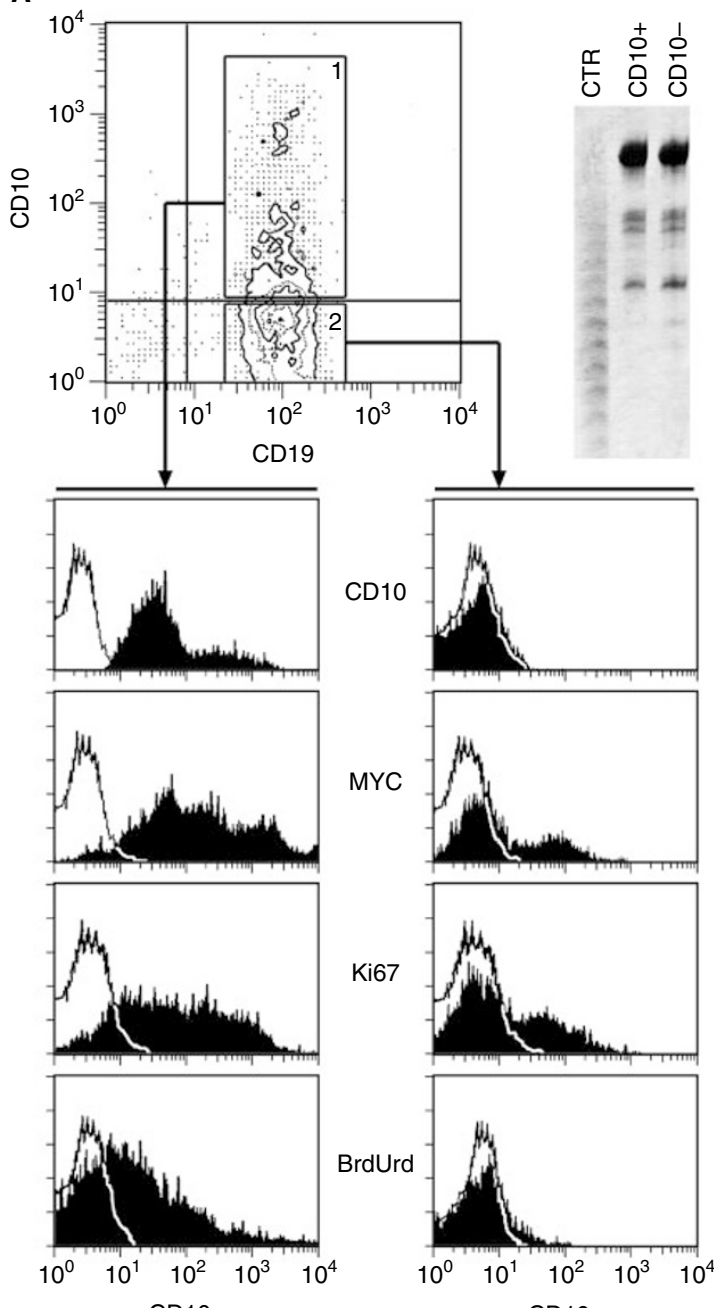

B

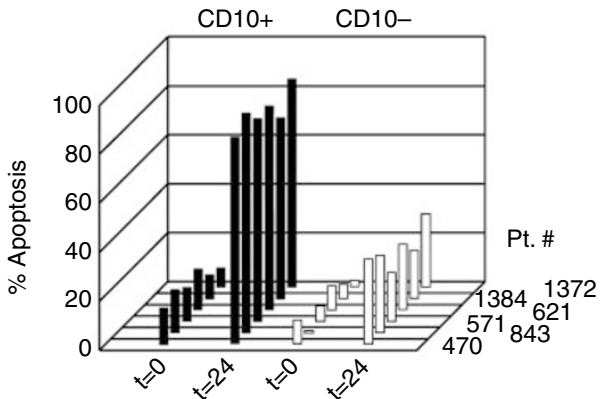

Figure 5 Features of CDI0-positive cells isolated from CDI0-negative ALL cases. (A) Cells from ALL case \#57I were stained for CDI 0 and separated as indicated. Both fractions contained cells from the same clone as assessed by $\vee(D)$ J length analysis (top right). Cells from the CDI0-positive and CDIO-negative cell fractions were stained for Myc and Ki67 or incubated with BrdUrd for $24 \mathrm{~h}$ before being stained with the appropriate reagents. The stained cells were analysed by flow cytometry. (B) The apoptotic capacities of CDI0-positive and CDI0-negative cell fractions purified from the indicated CDI0-negative ALL cases were measured by $\mathrm{Pl}$ staining before and after $24 \mathrm{~h}$ in culture.

In another series of experiments, freshly prepared cells were incubated with PNA-myc $c_{w t}$-NLS, PNA-myc $c_{\text {mut }}$-NLS or medium for $24 \mathrm{~h}$. Subsequently, apoptosis was measured by PI or Annex- 
A

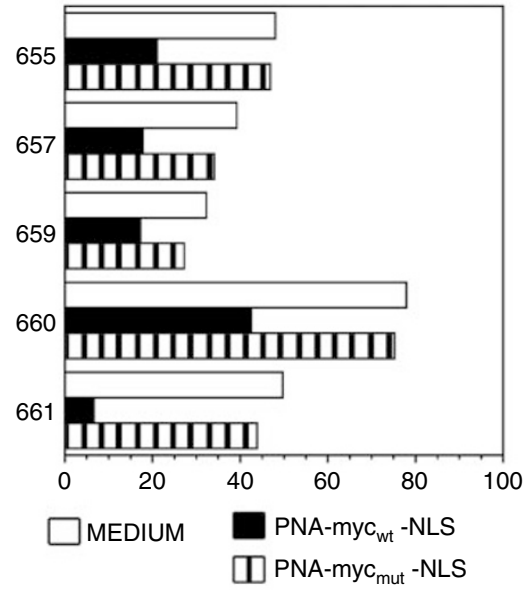

B

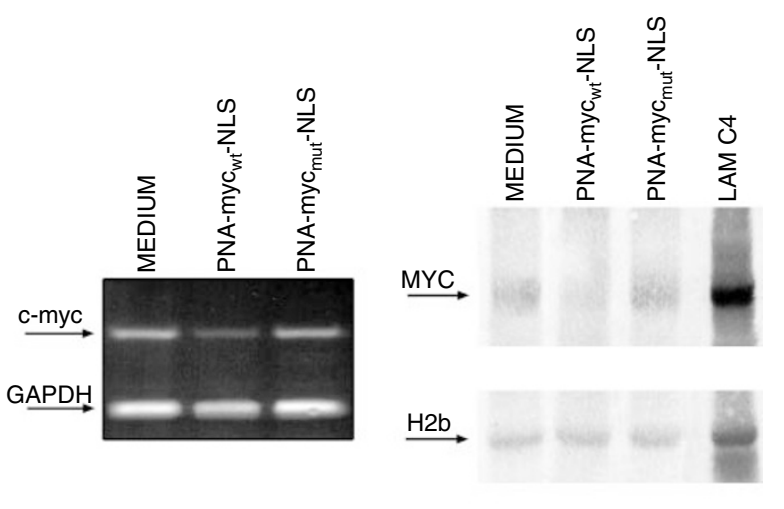

D
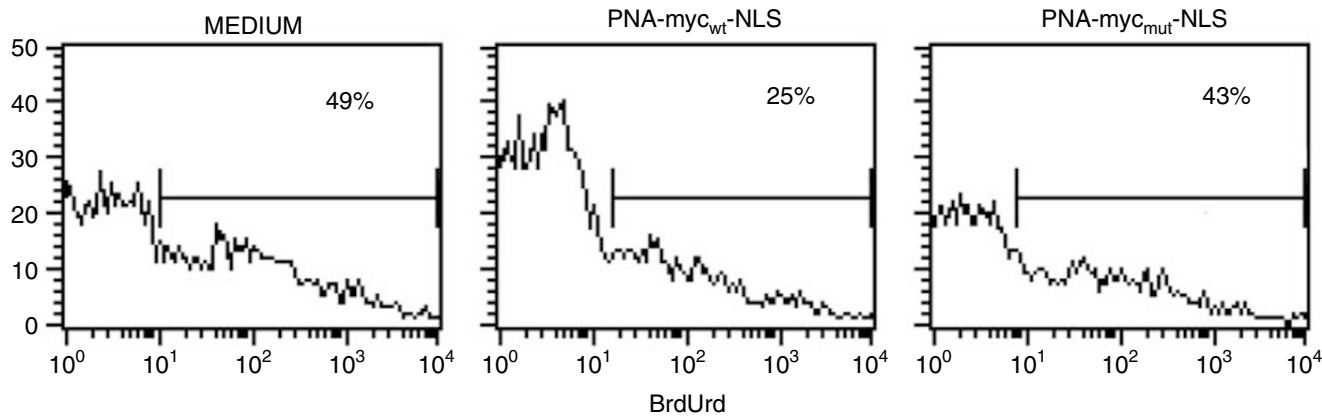

Figure 6 Inhibition of c-myc expression by PNA-myc ${ }_{w t}-N L S$. (A) The indicated CD I 0-positive ALL were incubated with PNA-myc ${ }_{w t}-N L S$, PNA-myc $c_{m u t}{ }^{-}$ NLS or medium for $24 \mathrm{~h}$ and analysed for Myc expression by flow cytometry. (B and C) Cells from one representative CDI0-positive ALL sample (\#66I) were cultured for $24 \mathrm{~h}$ and analysed for c-myc expression by RT-PCR (B) and Western blot (C). (C) Cells from one CDI0-positive ALL case (\#657) were treated with the indicated reagents for $24 \mathrm{~h}$, pulsed with BrdUrd for I h and analysed by flow cytometry to determine the fraction of the cells in the $\mathrm{S}$ phase of the cell cycle.

in- $\mathrm{V}$ staining and flow cytometry. A substantial inhibition of apoptosis (mean reduction $49.4 \pm 16.8 \%$ ) was noticed in all of the five cases tested. Figure 7A shows all of the data obtained by PI staining, which was indicative of both methods used (Figure 7B).

Finally, we checked whether a block in $\mathrm{c}-m y c$ expression caused a concomitant reduction in CD10-expression. As shown in Figure 8 , in the four cases that were investigated, there was a substantial inhibition (mean reduction $48 \pm 4.3 \%$ ) of CD10 expression as assessed by flow cytometry (Figure 8).

\section{DISCUSSION}

This study demonstrates that malignant B cells of CD10-positive ALL are mostly actively cycling, and are apoptosis-prone, whereas the cells of CD10-negative ALL are not actively cycling, and do not undergo apoptosis readily in vitro. In addition, the present data show a close correlation between Myc levels and the cycling and apoptotic capacities of the cells. Finally, these studies indicate that CD10 expression distinguishes cells with different properties.

Various results from this study point to correlations between CD10 expression and the cells' biological behaviour in vitro. The few CD10-positive malignant cells, present in those cases classified as CD10-negative ALL, shared all of the characteristics of the malignant cells found in the CD10-positive ALL cases, including elevated $c-m y c$ levels and the propensity to undergo spontaneous apoptosis. Furthermore, the block imposed on c-myc expression by PNA myc $\mathrm{wt}_{\mathrm{wt}}$-NLS was followed by inhibition of cell cycling, as well as of the apoptotic capacities of the ALL cells. Upon c-myc inhibition, there was also a substantial reduction of CD10 expression, thus confirming the value of $\mathrm{CD} 10$ as a marker for cycling and/or apoptosing ALL cells.

A wide range of results for Ki67 staining and BrUrd incorporation in ALL cases was reported in previous studies, but these features were not correlated with the immunophenotype of the malignant cells (Tsurusawa et al, 1995; Salomons et al, 1999).

Admittedly, most of the cases reported could have been CD10positve. This raises the questions as only in those cases the proliferative capacities of the leukaemic cells were in general lower than those observed for CD10-positive ALL cases in the present study. Although there are no apparent explanations for these differences, one should, however, point out that the flow cytometry method used here may have increased the ability of the techniques to detect cycling cells.

The present study indicates a fundamental role of $c-m y c$ in the apoptosis of ALL cells, since spontaneous cell death occurred in vitro only in those cells that displayed elevated c-myc levels. Whether this correlation holds true also for other types of apoptosis (e.g. drug or radiation induced) has to be further investigated, although studies on different cell types overexpressing c-myc would predict this to be the case (Rowe et al, 1987; Cutrona et al, 1995, 1997, 1999; de-Saint-Vis et al, 1995; Martinez-Valdez et al, 1996; Mueller et al, 1997; Guedez et al, 1998a,b). A close correlation between c-myc expression and apoptosis was first indicated by studies on murine fibroblasts transfected with the c-myc oncogene (Evan et al, 1992). Recent studies on cells induced to overexpress cmyc in vitro have demonstrated that these cells have difficulties in 
A

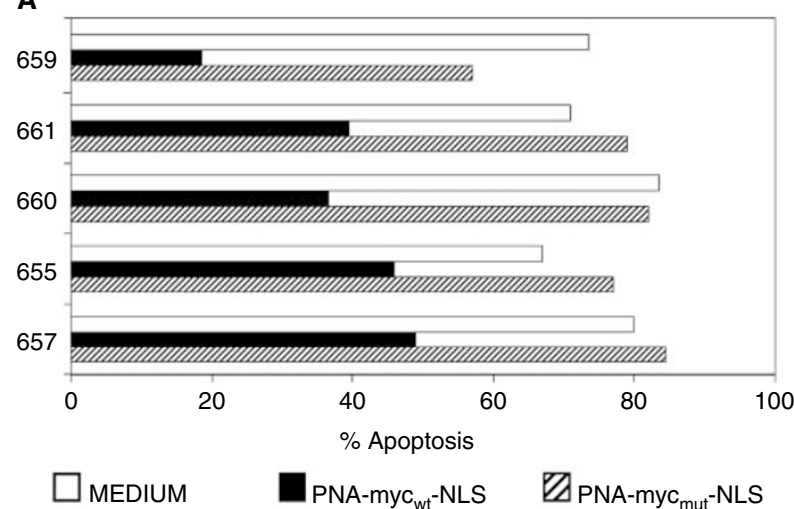

B

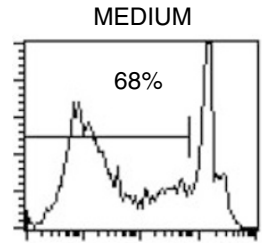

PNA-myc ${ }_{w t}-\mathrm{NLS}$

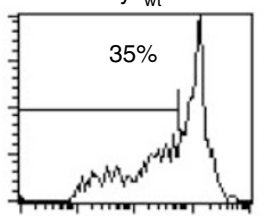

DNA content
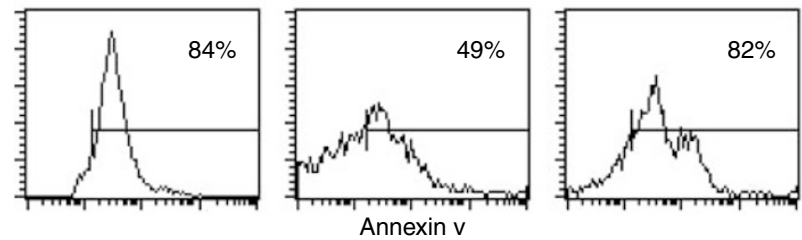

Figure 7 Inhibition of apoptosis in CDI0-positive ALL cells by PNAmy $\mathrm{c}_{w t}-\mathrm{NLS}$. (A) Cells from the indicated cases were exposed to the indicated PNAs or to medium alone for $24 \mathrm{~h}$ in vitro. Apoptosis was then measured by PI or Annexin-V-FITC staining (not shown). (B) Apoptotis of cells from case \#660 measured by PI or Annexin-V-staining. The cells were exposed to the indicated PNAs for $24 \mathrm{~h}$ in vitro prior to the test for apoptosis.

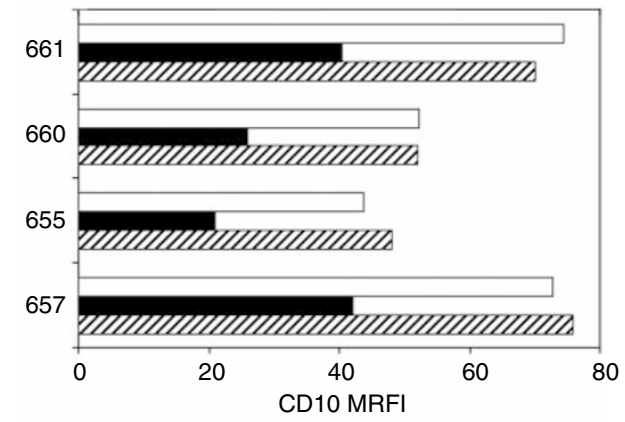

$\square$ MEDIUM $\square$ PNA-myc $\mathrm{wt}_{\mathrm{wt}}-\mathrm{NLS} \quad \square \mathrm{PNA}-\mathrm{myc}_{\mathrm{mut}}-\mathrm{NLS}$

Figure 8 Inhibition of CDIO expression by PNA-myc mut-NLS. Cells from the indicated CDI0-positive ALL cases were treated with PNAs or medium alone for $24 \mathrm{~h}$ in culture and subsequently stained for CDI0. Fluorescence was measured by flow-cytometry and expressed as MFRI.

completing cell cycle and usually either undergo apoptosis from the late G1 phase or remain arrested in the G2 phase. These arrested cells have a tendency to become aneuploid (often hyperdiploid) (Felsher et al, 2000). The latter mechanism observed in vitro may suggest an appealing model to explain the frequent hyperdiploidy seen in CD10-positive ALL cells. In this respect, it is of note that hyperdiploidy was detected in $41.7 \%$ of the CD10-positive ALL cases studied (five out of 12, Table 1) (see also reviews Look, 1997; Faderl et al, 1998; Ito et al, 1999).

The finding of elevated c-myc levels raises questions regarding the mechanisms involved in c-myc overexpression in CD10-positive ALL cells. Chromosomal translocations typical of BL and L3 leukaemias, which juxtapose c-myc to the Ig gene loci and cause c-myc overexpression, were excluded in all of the ALL cases selected for this study. Therefore, other options have to be considered. One possibility is that, because of the neoplastic transformation, the CD10-positive ALL cells were frozen at a maturational stage characterised by a physiological c-myc elevation and active cycling capacities. Studies on murine B cells have demonstrated that under particular circumstances, pre-B cells may proliferate autonomously in vitro (Rolink et al, 2000) and conceivably also in vivo (Carsetti, 2000). Moreover, there is evidence in man that most CD10-positive pre-B cells are actively cycling in vivo (Ghia et al, 1996). Another plausible, and not mutually exclusive, option is that alterations of oncogenes other than c-myc could be responsible for the malignant transformation and for the upregulation of $c-m y c$ (and cell proliferation). Finally, it is possible that in ALL cells the c-myc gene presented a number of mutations which prolong the intracellular half-life of its product, similar to that reported in certain BL cells (Bahram et al, 2000; Fais et al, 2000). Central to this issue is the problem of whether ALL cells express physiological (i.e. similar to those seen in proliferating cells) or pathological (i.e. similar to levels of those of BL) c-myc. Definitive proof for one or other hypothesis awaits further studies.

Previous investigations on cells with elevated c-myc levels have indicated that the choice between apoptosis or cell proliferation is often dictated by the presence of additional signals capable of promoting or preventing apoptosis (Bissonnette et al, 1992; Fanidi et al, 1992). For example, B cells in which the c-myc oncogene has been transfected and hyper-expressed would die in low serum concentrations in vitro unless exposed to $\mathrm{CD} 40 \mathrm{~L}$ or to an agonistic $\mathrm{CD} 40 \mathrm{mAb}$ which are both capable of inducing the upregulation of bcl2 and possibly of other anti-apoptotic genes (Cutrona et al, 1995). These observations suggest that a number of signals, delivered either by contact with stromal cells or by cytokines, prevent the apoptosis of CD10-positive ALL cells in vivo and facilitate their proliferation (Welch et al, 1990; Manabe et al, 1992, 1994; Saeland et al, 1992; Campana et al, 1994; Murti et al, 1996; Nishigaki et al, 1997). In this regard, it is of note that previous studies demonstrated that the ability of ALL cells to survive when cultured on stromal cells was an accurate predictor of a negative clinical outcome irrespective of the cell proliferative ability in vitro, possibly underlying the value of the anti-apoptotic properties of the stromal cells in the survival/expansion of the malignant ALL cells (Campana et al, 1993; Coustan-Smith et al, 1996; Kumagai et al, 1996).

Both CD10-positive and CD10-negative ALL are comprised of a heterogeneous group of diseases characterised by different cytogenetic abnormalities. Although data on such abnormalities are not available for all of the cases studied here, observations on a proportion of the CD10-positive ALL points to their heterogeneity. Thus, the $\mathrm{t}(4 ; 11)$ translocation, which involves MLL-AF4 gene (Pui et al, 1991 ), was found in only one out of 14 CD10-positive and 2/10 CD10-negative ALL cases. Likewise $\mathrm{t}(12 ; 21)$ causing TEL-AML1 (Romana et al, 1995; McLean et al, 1996; Borkhardt et al, 1997) rearrangement was seen in three out of 14 CD10-positive ALL cases.

The latter findings perhaps suggest a marginal involvement of these translocations in the control of $c-m y c$ expression. On the other hand, the intrinsic properties of the cells from the CD10negative ALL do not prevent them from expressing CD10 as shown by the data in Figure 5, which reinforced the concept that CD10 expression is linked to the cycling/apoptotic properties. This consideration may in part explain why CD10 expression represents a non-independent prognostic marker of ALL. Thus, the superior 
cycling and apoptotic features of CD10-positive ALL cells may render them more susceptible to the external signals including chemotherapeutic agents. However, additional features independent of the cycling/apoptotic capacities of the cells may also greatly influence the course of the disease.

\section{ACKNOWLEDGEMENTS}

We thank Mrs M Ulivi for revising the manuscript, Drs F Fais and S Zupo for helpful discussion, Mrs T Tavilla for excellent assistance

\section{REFERENCES}

Armitage P, Berry G (1987) Statistical Methods in Medical Research, London: Blackwell Scientific Publications

Bahram F, von der Lehr N, Cetinkaya C, Larsson LG (2000) c-Myc hot spot mutations in lymphomas result in inefficient ubiquitination and decreased proteasome-mediated turnover. Blood 15: 2104-2110

Bennett J, Catovsky D, Daniel MT, Flandrin G, Galton DA, Gralnick HR, Sultan C (1981) The morphological classification of acute lymphoblastic leukaemia: concordance among observers and clinical correlations. $\mathrm{Br}$ Haematol 47: 553-561

Bissonnette R, Echeverri F, Mahboubi A, Green DR (1992) Apoptotic cell death induced by c-myc is inhibited by bcl-2. Nature 359: $552-554$

Borkhardt A, Cazzaniga G, Viehmann S, Valsecchi MG, Ludwig WD, Burci L, Mangioni S, Schrappe M, Riehm H, Lampert F, Basso G, Masera G, Harbott J, Biondi A (1997) Incidence and clinical relevance of TEL/ AML1 fusion genes in children with acute lymphoblastic leukemia enrolled in the German and Italian multicenter therapy trials. Associazione Italiana Ematologia Oncologia Pediatrica and the Berlin-Frankfurt-Munster Study Group. Blood 90: 571-577

Campana D, Coustan Smith E, Kumagai MA, Manabe A (1994) Growth requirements of normal and leukemic human B cell progenitors. LeukLymphoma 13: $359-371$

Campana D, Coustan Smith E, Manabe A, Buschle M, Raimondi SC, Behm FG, Ashmun R, Arico M, Biondi A, Pui CH (1993) Prolonged survival of B-lineage acute lymphoblastic leukemia cells is accompanied by overexpression of bcl-2 protein. Blood 81: 1025-1031

Carsetti R (2000) The development of B cells in the bone marrow is controlled by the balance between cell-autonomous mechanisms and signals from the microenvironment. J Exp Med 191: 5-8

Consolini R, Legitimo A, Rondelli R, Guguelmi C, Barisone E, Lippi A, Cantu Rajnoldi A, Arico M, Conter V, Cocito MG, Putti MC, Pession A, Masera G, Biondi A, Basso G (1998) Clinical relevance of CD10 expression in childhood ALL. The Italian Association for Pediatric Hematology and Oncology (AIEOP). Haematologica 83: 967-973

Coustan-Smith E, Kitanaka A, Pui CH, McNinch L, Evans WE, Raimondi SC, Behm FG, Arico M, Campana D (1996) Clinical relevance of BCL-2 overexpression in childhood acute lymphoblastic leukemia. Blood 87: 1140 1146

Cutrona G, Carpaneto EM, Ulivi M, Roncella S, Landt O, Ferrarini M, Boffa LC (2000) Effects in live cells of a c-myc anti-gene PNA linked to a nuclear localization signal. Nat Biotechnol 18: 300-303

Cutrona G, Dono M, Pastorino S, Ulivi M, Burgio VL, Zupo S, Roncella S, Ferrarini M (1997) The propensity to apoptosis of centrocytes and centroblasts correlates with elevated levels of intracellular myc protein. Eur $J$ Immunol 27: $234-238$

Cutrona G, Leanza N, Ulivi M, Melioli G, Burgio VL, Mazzarello G, Gabutti G (1999) Expression of CD10 by human T cells that undergo apoptosis both in vitro and in vivo. Blood 94: 3067-3076

Cutrona G, Ulivi M, Fais F, Roncella S, Ferrarini M (1995) Transfection of the c-myc oncogene into normal Epstein-Barr virus-harboring B cells results in new phenotypic and functional features resembling those of Burkitt lymphoma cells and normal centroblasts. J Exp Med 181: 699711

de-Saint-Vis B, Cupillard L, Pandrau Garcia D, Ho S, Renard N, Grouard G, Duvert V, Thomas X, Galizzi JP, Banchereau J (1995) Distribution of carboxypeptidase $\mathrm{M}$ on lymphoid and myeloid cells parallels the other zinc-dependent proteases CD10 and CD13. Blood 86: 1098-1105 in the preparation of this manuscript. This work was supported by grants from Associazione Italiana per la Ricerca sul Cancro (AIRC to M Ferrarini, V Pistoia, LC Boffa and G Basso), Consiglio Nazionale delle Ricerche progetto 'Biotechnology' (to LC Boffa), Progetto Finalizzato Ministero della Sanità (to V Pistoia), MURST (to M Ferrarini, G Basso) and Fondazione Città della Speranza (to G Basso); Associazione Italiana contro le Leucemie (AIL) - sezione A. Neri Reggio Calabria, and Progetto Onco-Ematologia Infantile Regione Calabria (to F Morabito), Istituto Superiore di Sanità AIDS project no 30C.29 to M Ferrarini, M Dono is a fellow of Istituto Superiore di Sanità (ISS) (AIDS project), programma CNRAgenzia 2000 project CNRC00AC9_001.
Dolbeare F, Beisker W, Pallavicini MG, Vanderlaan M, Gray JW (1985) Cytochemistry for bromodeoxyuridine/DNA analysis: stoichiometry and sensitivity. Cytometry 6: $521-530$

Dono M, Hashimoto S, Fais F, Trejo V, Allen SL, Lichtman SM, Schulman P, Vinciguerra VP, Sellars B, Gregersen PK, Ferrarini M, Chiorazzi N (1996) Evidence for progenitors of chronic lymphocytic leukemia B cells that undergo intraclonal differentiation and diversification. Blood 87: 15861594

Egholm M, Buchardt O, Christensen L, Behrens C, Freier SM, Driver DA, Berg RH, Kim SK, Norden B, Nielsen PE (1993) PNA hybridizes to complementary oligonucleotides obeying the Watson-Crick hydrogenbonding rules. [see comments] Nature 365: 566-568

Egholm M, Buchardt O, Nielsen PE, Berg RH (1992) Peptide Nucleic Acid (PNA). Oligonucleotides analogues with an achiral peptide backbone. $J$ Am Chem Soc 114: 1895-1897

Evan G, Wyllie AH, Gilbert CS, Littlewood TD, Land H, Brooks M, Waters CM, Penn LZ, Hancock DC (1992) Induction of apoptosis in fibroblasts by c-myc protein. Cell 69: $119-128$

Faderl S, Kantariian HM, Talpaz M, Estrov Z (1998) Clinical significance of cytogenetic abnormalities in adult acute lymphoblastic leukemia. Blood 91: $3995-4019$

Fais F, Fronza G, Roncella S, Inga A, Campomenosi P, Cutrona G, Pezzolo A, Fedeli F, Abbondandolo A, Chiorazzi N, Pistoia V, Ferrarini M (2000) Analysis of stepwise genetic changes in an AIDS-related Burkitt's lymphoma. Int J Cancer 88: 744-750

Fanidi A, Harrington EA, Evan GI (1992) Cooperative interaction between cmyc and bcl-2 proto-oncogenes. Nature 359: 554-556

Felsher D, Zetterberg A, Zhu J, Tlsty T, Bishop JM (2000) Overexpression of MYC causes p53-dependent G2 arrest of normal fibroblasts. Proc Natl Acad Sci USA 97: $10544-10548$

Gerdes J, Lemke H, Baisch H, Wacker HH, Schwab U, Stein H (1984) Cell cycle analysis of a cell proliferation-associated human nuclear antigen defined by the monoclonal antibody Ki-67. J Immunol 133: 1710-1715

Ghia P, ten Boekel E, Sanz E, de la Hera A, Rolink A, Melchers F (1996) Ordering of human bone marrow B lymphocyte precursors by single-cell polymerase chain reaction analyses of the rearrangement status of the immunoglobulin H and L chain gene loci. J Exp Med 184: 2217-2229

Guedez L, Courtemanch L, Stetler Stevenson M (1998a) Tissue inhibitor of metalloproteinase (TIMP)-1 induces differentiation and an antiapoptotic phenotype in germinal center B cells. Blood 92: 1342-1349

Guedez L, Stetler Stevenson WG, Wolff L, Wang J, Fukushima P, Mansoor A, Stetler Stevenson M (1998b) In vitro suppression of programmed cell death of B cells by tissue inhibitor of metalloproteinases-1. J Clin Invest 102: $2002-2010$

Hann SR, Eisenman RN (1984) Proteins encoded by the human c-myc oncogene: differential expression in neoplastic cells. Mol Cell Biol 4: 2486-2497

Hueber AO, Evan GI (1998) Traps to catch unwary oncogenes. Trends Genet 14: $364-367$

Ito C, Kumagai M, Manabe A, Coustan Smith E, Raimondi SC, Behm FG, Murti KG, Rubnitz JE, Pui CH, Campana D (1999) Hyperdiploid acute lymphoblastic leukemia with 51 to 65 chromosomes: a distinct biological entity with a marked propensity to undergo apoptosis. Blood 93: 315-320

Kumagai M, Manabe A, Pui CH, Behm FG, Raimondi SC, Hancock ML, Mahmoud H, Crist WM, Campana D (1996) Stroma-supported culture in childhood B-lineage acute lymphoblastic leukemia cells predicts treatment outcome. J Clin Invest 97: 755-760 
LeBien TW, McCormack RT (1989) The common acute lymphoblastic leukemia antigen (CD10)-emancipation from a functional enigma. Blood 73: $625-635$

Liu YJ, Johnson GD, Gordon J, MacLennan IC (1992) Germinal centres in Tcell-dependent antibody responses. Immunol Today 13: 17-21

Look AT (1997) Oncogenic transcription factors in the human acute leukemias. Science 278: 1059 - 1064

Magrath I (1990) The pathogenesis of Burkitt's lymphoma. Adv Cancer Res 55: $133-270$

Manabe A, Coustan Smith E, Behm FG, Raimondi SC, Campana D (1992) Bone marrow-derived stromal cells prevent apoptotic cell death in B-lineage acute lymphoblastic leukemia. Blood 79: 2370-2377

Manabe A, Murti KG, Coustan Smith E, Kumagai M, Behm FG, Raimondi SC, Campana D (1994) Adhesion-dependent survival of normal and leukemic human B lymphoblasts on bone marrow stromal cells. Blood 83: 758 766

Martinez-Valdez H, Guret C, de Bouteiller O, Fugier I, Banchereau J, Liu YJ (1996) Human germinal center B cells express the apoptosis-inducing genes Fas, c-myc, P53, and Bax but not the survival gene bcl-2. J Exp Med 183: $971-977$

McLean TW, Ringold S, Neuberg D, Stegmaier K, Tantravahi R, Ritz J, Koeffler HP, Takeuchi S, Janssen JW, Seriu T, Bartram CR, Sallan SE, Gilliland DG, Golub TR (1996) TEL/AML-1 dimerizes and is associated with a favorable outcome in childhood acute lymphoblastic leukemia. Blood 88: $4252-4258$

Mitelman F (1995) ISCN: An international System for Human Cytogenetic. Nomenclature. Basel: S Karger

Mueller CG, Rissoan MC, Salinas B, Ait Yahia S, Ravel O, Bridon JM, Briere F, Lebecque S, Liu YJ (1997) Polymerase chain reaction selects a novel disintegrin proteinase from CD40-activated germinal center dendritic cells. $J$ Exp Med 186: 655-663

Murti KG, Brown PS, Kumagai M, Campana D (1996) Molecular interactions between human B-cell progenitors and the bone marrow microenvironment. Exp Cell Res 226: 47-58

Nielsen PE (1999) Peptide nucleic acids as therapeutic agents. Curr Opin Struct Biol 9: $353-357$

Nishigaki H, Ito C, Manabe A, Kumagai M, Coustan Smith E, Yanishevski Y, Behm FG, Raimondi SC, Pui CH, Campana D (1997) Prevalence and growth characteristics of malignant stem cells in B-lineage acute lymphoblastic leukemia. Blood 89: $3735-3744$

Pui CH, Frankel LS, Carroll AJ, Raimondi SC, Shuster JJ, Head DR, Crist WM, Land VJ, Pullen DJ, Steuber CP (1991) Clinical characteristics and treatment outcome of childhood acute lymphoblastic leukemia with the $\mathrm{t}(4 ; 11)(\mathrm{q} 21 ; \mathrm{q} 23)$ : a collaborative study of 40 cases. [see comments] Blood 77: $440-447$

Pui CH, Rivera GK, Hancock ML, Raimondi SC, Sandlund JT, Mahmoud HH, Ribeiro RC, Furman WL, Hurwitz CA, Crist WM (1993) Clinical significance of CD10 expression in childhood acute lymphoblastic leukemia. Leukemia 7: $35-40$
Rolink AG, Winkler T, Melchers F, Andersson J (2000) Precursor B cell receptor-dependent $\mathrm{B}$ cell proliferation and differentiation does not require the bone marrow or fetal liver environment. J Exp Med 191: 23-32

Romana SP, Poirel H, Leconiat M, Flexor MA, Mauchauffe M, Jonveaux P, Macintyre EA, Berger R, Bernard OA (1995) High frequency of $t(12 ; 21)$ in childhood B-lineage acute lymphoblastic leukemia. Blood 86: 4263 4269

Roncella S, Di Celle PF, Cutrona G, Carbone A, Sessarego M, Landonio G, Foa R, Rowe M, Ferrarini M (1993) Cytogenetic rearrangement of CMYC oncogene occurs prior to infection with Epstein-Barr virus in the monoclonal malignant B cells from an AIDS patient. Leuk Lymphoma 9: $157-164$

Rowe M, Rowe DT, Gregory CD, Young LS, Farrell PJ, Rupani H, Rickinson AB (1987) Differences in B cell growth phenotype reflect novel patterns of Epstein-Barr virus latent gene expression in Burkitt's lymphoma cells. EMBO J 6: $2743-2751$

Saeland S, Moreau I, Duvert V, Pandrau D, Bancherau J (1992) In vitro growth and maturation of human B-cell precursors. Curr Top Microbiol Immunol 182: $85-94$

Sainati L, Leszl A, Putti M, Pasquali F, Maserati E, Donti E, Venti G, Simi P, Giuliani C, Angioni A, Stella M, Montaldi A, Sessarego M, Zanesco L, Biondi A, Basso G (1997) Centralized cytogenetic analysis of pediatric acute leukemia: results of an Italian collaborative experience. Haematologica 82: $654-659$

Salomons GS, Smets LA, Verwijs-Janssen M, Hart AA, Haarman EG, Kaspers GJ (1999) Bcl-2 family members in childhood acute lymphoblastic leukemia: relationships with features at presentation, in vitro and in vivo drug response and long-term clinical outcome. Leukemia 13: $1574-1580$

Shipp MA, Look AT (1993) Hematopoietic differentiation antigens that are membrane-associated enzymes: cutting is the key! Blood 82: $1052-1070$

Tsurusawa M, Aoyama M, Saeki K, Fujimoto T (1995) Cell cycle kinetics in childhood acute leukemia studied with in vitro bromodeoxyuridine labeling, Ki67-reactivity, and flow cytometry. Leukemia 9: 1921-1925

van-Dongen JJ, Macintyre EA, Gabert JA, Delabesse E, Rossi V, Saglio G, Gottardi E, Rambaldi A, Dotti G, Griesinger F, Parreira A, Gameiro P, Diaz MG, Malec M, Langerak AW, San-Miguel JF, Biondi A (1999) Standardized RT-PCR analysis of fusion gene transcripts from chromosome aberrations in acute leukemia for detection of minimal residual disease. Report of the BIOMED-1 Concerted Action: investigation of minimal residual disease in acute leukemia. Leukemia 13: $1901-1928$

Weir EG, Borowitz MJ (2001) Flow cytometry in the diagnosis of acute leukemia. Semin Hematol 38: $124-138$

Welch PA, Burrows PD, Namen A, Gillis S, Cooper MD (1990) Bone marrow stromal cells and interleukin-7 induce coordinate expression of the BP-1/ 6C3 antigen and pre-B cell growth. Int Immunol 2: 697-705 